\title{
Application of the International Germ Cell Consensus Classification to the Nova Scotia population of patients with germ cell tumours
}

\author{
Elana Maydanski Murphy, MD; Jo-Anne Douglas, BSc; ${ }^{\dagger}$ Kara Thompson, MSc, BSc; ${ }^{\dagger}$ \\ Lori Wood, MD, MSc"t
}

\begin{abstract}
Background: The International Germ Cell Consensus Classification (IGCCC) is the internationally accepted, clinically based prognostic classification used to assist in the management and research of metastatic germ cell tumours (GCTs). The goal of this study was to determine whether the IGCCC is applicable to a populationbased cohort.
\end{abstract}

Methods: We completed a retrospective chart review of patients who received diagnoses of GCT in Nova Scotia between 1984 and 2004 and who received treatment with platin-based chemotherapy for metastatic disease. We assigned the IGCCC to each patient based on the site of the primary lesion, the presence or absence of nonpulmonary visceral metastases and prechemotherapy tumour marker values. We calculated Kaplan-Meier estimates of 5-year progression-free survival (PFS) and overall survival for each IGCCC group.

Results: The study cohort comprised 129 patients. The distribution and outcomes in each group of patients in Nova Scotia was similar to that published in the IGCCC. Among patients with nonseminoma GCTs (NSGCT) $61 \%$ had good, $22 \%$ had intermediate and $17 \%$ had poor prognoses. Among those with seminomas, $85 \%$ had good and $15 \%$ had intermediate prognoses. Among patients with NSGCTs, the 5 -year PFS was $90 \%, 69 \%$ and $55 \%$, and the 5 -year overall survival was 94\%, 84\%, 61\% in the good, intermediate, and poor prognostic categories respectively. Among patients with seminomas, the 5 -year PFS was $95 \%$ and $50 \%$ and the 5 -year overall survival was $94 \%$ and $50 \%$ in the good and intermediate prognostic categories, respectively.

Conclusion: The IGCCC seems applicable to a population-based cohort, with similar distribution of categories and clear prognostic ability.

Can Urol Assoc J 2009;3(2):120-4

\section{Résumé}

Contexte : L'IGCCC (International Germ Cell Consensus Classification) est un système de classification pronostique mondialement reconnu, basé sur les données cliniques et utilisé pour faciliter la prise en charge des tumeurs germinales métastatiques et la recherche sur ces tumeurs. Le but de la présente étude était de déterminer si cette classification s'applique à une cohorte de population.
Méthodologie : On a mené une étude rétrospective par examen de dossiers de patients ayant reçu un diagnostic de tumeur germinale en Nouvelle-Écosse entre 1984 et 2004 et traités par chimiothérapie antimétastatique à base de platine. On a classé les patients selon I'IGCCC en fonction du siège de la tumeur primitive, de la présence ou de l'absence de métastases viscérales non pulmonaires et des valeurs des marqueurs tumoraux avant la chimiothérapie. La survie sans progression de la maladie (SSP) et la survie globale (SG) sur 5 ans pour chaque groupe formé en fonction de I'IGCCC ont été évaluées par la méthode de Kaplan-Meier.

Résulfats : La cohorte étudiée comptait 129 patients. La distribution et I'issue du traitement étaient similaires pour tous les patients à celles publiées dans la classification IGCCC. Chez les patients avec tumeurs germinales non séminomateuses, $61 \%$ avaient un pronostic favorable, $22 \%$ un pronostic moyen et $17 \%$ un pronostic médiocre. Chez les patients avec tumeurs séminomateuses, $85 \%$ avaient un pronostic favorable et $15 \%$ un pronostic moyen. Chez les patients avec tumeurs germinales non séminomateuses, la SSP après 5 ans était de $90 \%$, $69 \%$ et $55 \%$ et la survie globale après 5 ans était de $94 \%, 84 \%$ et $61 \%$ en fonction de pronostiques favorable, moyen et médiocre, respectivement. Chez les patients avec tumeurs séminomateuses, la SSP après 5 ans était de $95 \%$ et $50 \%$ et la survie globale après 5 ans était de $94 \%$ et $50 \%$ en fonction de ces mêmes catégories pronostiques. Conclusion : L'IGCCC semble bien s'appliquer à une cohorte de population; la distribution entre les classes est similaire, et la capacité pronostique est très bonne.

\section{Introduction}

Germ cell tumours (GCTs) are the most common solid cancers with a rising incidence in young men. ${ }^{1,2}$ The tumours can be classified into 2 major histological types: seminoma and nonseminoma germ cell tumours (NSGCT), with seminomas comprising about $40 \%-50 \%$ of GCTs and NSGCTs comprising 50\%-60\%.

The approval of cisplatin in 1978 led to improved outcomes in this patient population, with cure rates exceeding $90 \% .{ }^{4}$ It was soon recognized, however, that many factors influenced the outcome of patients with advanced disease. These factors included the extent and sites of metastatic spread, the primary site, tumour size and the 
degree of tumour marker elevation. Different prognostic factor classification systems were developed in different institutions and countries in an attempt to divide patients into prognostic groups for both clinical and research purposes..$^{5-7}$ These classification systems included different variables and varied substantially. A comparison of different classification systems was performed and poor agreement was achieved when assigning patients into good- or poor-risk categories. ${ }^{8}$ Because of these differences, comparison of different trials and databases or collaboration in randomized clinical trials was difficult.

In 1991, the International Germ Cell Cancer Collaborative Group comprising international researchers and clinicians was formed to develop a stratification system for use in both clinical practice and clinical trials. In 1997, the International Germ Cell Consensus Classification (IGCCC) was published and has become the gold standard used in daily clinical practice and GCT research. ${ }^{9}$ Independent prognostic variables include histology of the primary tumour, site of the primary tumour, the degree of pretreatment tumour marker elevation ( $\alpha$ fetoprotein [AFP], human chorionic gonadotrophin and lactate dehydrogenase) and the presence of nonpulmonary visceral metastases, as seen in Table 1.

The IGCCC was derived from the pooled clinical data from 5202 patients with NSGCTs and 660 patients with seminomas treated between 1975 and 1990 using platin-based chemotherapy. These patients were treated at specific, wellrecognized centres with an expertise in the management of GCTs.

The goal of our study was to determine whether the IGCCC can be applied to a population-based cohort of patients with GCTs. The specific aim was to determine the proportion and outcomes of patients with metastatic GCTs treated with platinbased chemotherapy in Nova Scotia who had good, intermediate and poor prognoses according to the IGCCC and to compare the Nova Scotia data with that reported in the IGCCC.

\section{Methods}

We obtained approval from our research ethics board. We performed a search of the QEII Health Science Centre Surveillance and Epidemiology Databases to identify patients with GCTs in Nova
Scotia diagnosed between 1984 and 2004. Patients in this geographic region have tended to be nonmigratory, which allows for fairly complete followup. We performed a retrospective chart review to determine which patients received platin-based chemotherapy for metastatic disease. Data collection included histology, location of primary site, presence and location of metastatic sites, serum levels of AFP, human chorionic gonadotropin (hCG) and lactate dehydrogenase (LDH) before chemotherapy, start and finish date of chemotherapy, date of disease progression, date of last contact and date of death.

We analyzed patients in 2 groups: 1) NSGCT (which also included patients with seminoma and an increased AFP) and 2) seminoma. We categorized patients into good, intermediate and poor prognosis groups, as per the IGCCC criteria.

\begin{tabular}{|c|c|c|}
\hline Histology & $\begin{array}{l}\text { Prognostic } \\
\text { category }\end{array}$ & Clinical factors \\
\hline \multirow[t]{12}{*}{ NSGCT } & Good & $\begin{array}{l}\text { Testes/retroperitoneal primary } \\
\text { and no nonpulmonary visceral } \\
\text { metastases and good markers: }\end{array}$ \\
\hline & & $\mathrm{AFP}<1000 \mathrm{ng} / \mathrm{mL}$ and \\
\hline & & hCG $<5000 \mathrm{IU} / \mathrm{L}$ and \\
\hline & & $\mathrm{LDH}<1.5 \times \mathrm{ULN}$ \\
\hline & \multirow[t]{4}{*}{ Intermediate } & $\begin{array}{l}\text { Testes/retroperitoneal primary } \\
\text { and no nonpulmonary visceral } \\
\text { metastases and intermediate } \\
\text { markers: }\end{array}$ \\
\hline & & $\begin{array}{l}\text { AFP } \geq 1000 \mathrm{ng} / \mathrm{mL} \text { and } \\
\leq 10000 \mathrm{ng} / \mathrm{mL} \text { or }\end{array}$ \\
\hline & & $\begin{array}{l}\mathrm{hCG} \geq 5000 \mathrm{IU} / \mathrm{L} \text { and } \\
\leq 50000 \mathrm{ng} / \mathrm{mL} \text { or }\end{array}$ \\
\hline & & $\begin{array}{l}\mathrm{LDH} \geq 1.5 \times \mathrm{ULN} \text { and } \\
\leq 10 \times \mathrm{ULN}\end{array}$ \\
\hline & \multirow[t]{4}{*}{ Poor } & $\begin{array}{l}\text { Mediastinal primary or } \\
\text { nonpulmonary visceral } \\
\text { metastases or poor markers with }\end{array}$ \\
\hline & & AFP $>10000 \mathrm{ng} / \mathrm{mL}$ or \\
\hline & & hCG > $50000 \mathrm{IU} / \mathrm{L}$ or \\
\hline & & $\mathrm{LDH}>10 \times \mathrm{ULN}$ \\
\hline \multirow[t]{2}{*}{ Seminoma } & Good & $\begin{array}{l}\text { Any primary site and no } \\
\text { nonpulmonary visceral metastases } \\
\text { and normal AFP, any hCG, any LDH }\end{array}$ \\
\hline & Intermediate & $\begin{array}{l}\text { Any primary site and nonpulmonary } \\
\text { visceral metastases and } \\
\text { normal AFP, any hCG, any LDH }\end{array}$ \\
\hline $\begin{array}{l}\text { AFP }=\alpha \text { fetoprc } \\
\text { dehydrogenase } \\
\text { normal. }\end{array}$ & $\mathrm{n} ; \mathrm{hCG}=$ human $\mathrm{c}$ & $\begin{array}{l}\text { rionic gonadotropin; } L D H=\text { lactate } \\
\text { a germ cell tumour; } U L N=\text { upper limit of }\end{array}$ \\
\hline
\end{tabular}


Primary outcomes in our study were identical to those in the IGCCC. We measured progressionfree survival (PFS) from the date of initial chemotherapy and defined it as freedom from progression of disease at any time after the start of chemotherapy or death from any cause. We measured overall survival from the date of initial chemotherapy.

We obtained follow-up data from the Nova Scotia Cancer Registry, the QEII Health Sciences Centre charts, the provincial radiology database, regional laboratory databases and the national death registry.

\section{Statistical analysis}

We used SAS version 8.2 (SAS Institute Inc.) to analyze the data. We calculated the PFS and overall

\begin{tabular}{|c|c|}
\hline Characteristic & No. $(\%)$ of patients \\
\hline \multicolumn{2}{|l|}{ Primary site } \\
\hline Testis & $117(91)$ \\
\hline Mediastinum & $6 \quad(5)$ \\
\hline Retroperitoneum & $2 \quad(2)$ \\
\hline Other & $4 \quad(3)$ \\
\hline \multicolumn{2}{|l|}{ Histology } \\
\hline NSGCT & 99 (77) \\
\hline Seminoma & $26(20)$ \\
\hline Unknown & $4 \quad(3)$ \\
\hline \multicolumn{2}{|l|}{ Nonpulmonary visceral metastases } \\
\hline Present & $16(12)$ \\
\hline Absent & $113(88)$ \\
\hline \multicolumn{2}{|l|}{ Tumour markers } \\
\hline \multicolumn{2}{|l|}{ AFP* } \\
\hline$<1000$ ng/mL & 94 (89) \\
\hline$\geq 1000$ and $\leq 10000 \mathrm{ng} / \mathrm{mL}$ & 10 \\
\hline$>10000$ ng/mL & $2 \quad(2)$ \\
\hline \multicolumn{2}{|l|}{$\mathrm{hCG}+$} \\
\hline$<5000 \mathrm{IU} / \mathrm{L}$ & 98 (88) \\
\hline$\geq 5000$ and $\leq 50000 \mathrm{lU} / \mathrm{L}$ & $6 \quad$ (5) \\
\hline$\geq 50000 \mathrm{IU} / \mathrm{L}$ & $7 \quad(6)$ \\
\hline \multicolumn{2}{|l|}{ LDH $\neq$} \\
\hline$<1.5 \times$ ULN & 47 (66) \\
\hline$\geq 1.5 \times$ and $\leq 10 \times$ ULN & $21(30)$ \\
\hline$>10 \times$ ULN & 3 (4) \\
\hline \multicolumn{2}{|c|}{$\begin{array}{l}\text { AFP }=\alpha \text { fetoprotein; } \mathrm{hCG}=\text { human chorionic gonadotropin; } L D H=\text { lactate } \\
\text { dehydrogenase; } N S G C T=\text { nonseminoma germ cell tumour; } U L N=\text { upper limit of } \\
\text { normal. } \\
\text { *Unknown in } 23 \text { patients. } \\
\text { tUnknown in } 18 \text { patients. } \\
\text { fUnknown in } 58 \text { patients. }\end{array}$} \\
\hline
\end{tabular}

survival using the Kaplan-Meier method. We analyzed $\mathrm{LDH}$ values as relative increases above the upper limit of normal. We considered AFP in nanograms per millilitre and hCG in international units to be absolute values. If tumour marker values were missing, we placed patients into prognostic categories based on the remaining data.

\section{Results}

Between 1984 and 2004, 425 patients received diagnoses of GCT in Nova Scotia. Of these, 132 patients had metastatic disease and received platin-based chemotherapy. We excluded 3 patients ( 1 who received prior chemotherapy, 1 whose treatment could not be ascertained and 1 who was younger than 16 years old). General information about our study population is provided in Table 2. The testis was the primary site in more than $90 \%$ of the patients. Nonseminoma GCTs accounted for more than $75 \%$ of all GCTs. Eight patients had seminoma and elevated AFP, thus we classified them in the NSGCT group. Only $12 \%$ of patients had nonpulmonary visceral spread of their cancer. The average age at the time of diagnosis was 32.1 years and the median follow-up time for surviving patients in the cohort was 6.1 years.

The distribution and outcomes of patients with good, intermediate and poor prognoses is shown in Table 3. The proportion of patients in Nova Scotia with good, intermediate and poor prognoses for NSGCTs was similar to that in the IGCCC $(61 \%$ v. $56 \%$ with good, $22 \%$ v. $28 \%$ with intermediate and $17 \%$ v. $16 \%$ with poor prognoses). The percentage of patients with good and intermediate prognoses for seminomas was also similar $(85 \%$ v. $90 \%$ with good and $15 \%$ v. $10 \%$ with intermediate prognoses).

The outcomes of the Nova Scotia cohort compared with those in the IGCCC are also shown in Table 3. Among patients with NSGCTs, the 5 -year PFS was $90 \%, 69 \%$ and $55 \%$ for patients with good, intermediate and poor prognoses, respectively. The 5 -year overall survival was $94 \%$, $84 \%$ and $61 \%$ for patients with good, intermediate and poor prognoses, respectively. This compares favourably to the IGCCC, although the 5 -year PFS for the intermediate and poor prognosis categories and the 5 -year overall survival for the poor prognosis category in our cohort fell outside the IGCCC confidence intervals (Cls). 
The outcomes for the NS cohort with seminoma revealed a 5 -year PFS of $95 \%$ and $50 \%$ among patients with good and intermediate prognoses, respectively. The 5 -year overall survival was $94 \%$ and $50 \%$ among patients with good and intermediate prognoses, respectively. The IGCCC did not publish Cls for 5-year PFS and overall survival, thus comparison is more difficult. The outcome for patients with good prognoses was slightly better in Nova Scotia, and the outcomes among thoses with intermediate prognoses was slightly worse.

\section{Discussion}

Although GCTs are uncommon, worldwide incidence of this cancer is on the rise. With the advent of platin-based chemotherapy, GCT has become one of the few curable cancers, even in the advanced stage or at relapse. An accurate prognostic classification system is required to guide physicians to make evidence-based decisions with regard to treatment, to appropriately advise patients on their prognoses and to optimize research to assist in clinical trial design and interpretation of results. The IGCCC was developed to meet these needs.

The IGCCC has become a gold standard used in decision-making for patients with metastatic GCTs and in clinical trials. Much of the data that provide the basis for the IGCCC, however, were obtained from specialized centres in the treatment of GCTs, which have been shown to produce better outcomes than nonspecialized or low-volume centres. ${ }^{10-13}$ Analyzing only patients from specialized centres may also introduce a referral bias because perhaps only a certain subset of patients, such as those perceived to have the worst prognoses, would be referred. ${ }^{14}$ In addition, much of the data come from patients who participated in clinical trials, which may also influence the outcome compared with a general population of treated patients. Whether the results of the IGCCC can be applied to a general patient population has not been proven.

Our study examined a general population from a later time period to determine whether the distribution of patients with good, intermediate or poor prognoses was similar to that in the IGCCC and whether the patient outcomes in terms of 5-year PFS and overall survival were comparable. Our study had limitations, including the small sample size, the variation of care over time, patients lost to follow-up, missing data and the fact that a direct statistical comparison between the patients in Nova Scotia and the IGCCC was not possible. The reason that the 5-year PFS among patients in the intermediate and poor prognosis categories and the 5-year overall survival among patients in the poor prognosis category for the NSGCT patients fell outside the IGCCC Cls was likely the small sample size, as evidenced by the wide $\mathrm{Cls}$ in our cohort. Our study also had strengths, the largest being that it was population-based and that the data were more recent.

The percentage of patients in Nova Scotia with diagnoses of GCT with good, intermediate and poor prognoses was very similar to that in the IGCCC, suggesting the patient populations were similar in terms of prognostic factors when treatment began. Our study showed that the patients with GCTs treated in Nova Scotia between 1984 and 2004 had similar outcomes to those in the consensus paper and that the IGCCC has clear prognostic ability in this population-based cohort. Our findings support the applicability of the IGCCC to a population-based

Table 3. Comparison of the distribution and outcomes of the Nova Scotia cohort to the International Germ Cell Consensus Classification

\begin{tabular}{|c|c|c|c|c|c|c|c|}
\hline \multirow[b]{2}{*}{ Group } & \multirow[b]{2}{*}{ Prognosis } & \multirow[b]{2}{*}{$\begin{array}{c}\text { No. }(\%) \text { of NS } \\
\text { patients }\end{array}$} & \multirow[b]{2}{*}{ IGCCC \% } & \multicolumn{4}{|c|}{$\%(95 \% \mathrm{Cl})$} \\
\hline & & & & NS 5-yr PFS & IGCCC 5-yr PFS & NS 5-yr OS & IGCCC 5-yr OS \\
\hline \multirow[t]{3}{*}{ NSGCT } & Good & $60(61)$ & 56 & 90 (78-96) & 89 (87-91) & 94 (82-98) & $92(90-94)$ \\
\hline & Intermediate & $22(22)$ & 28 & 69 (37-84) & 75 (71-79) & $84(55-92)$ & $80(76-84)$ \\
\hline & Poor & $17(17)$ & 16 & 55 (27-76) & $41(35-47)$ & $61(33-80)$ & $48(42-54)$ \\
\hline \multirow[t]{2}{*}{ Seminoma } & Good & $22(85)$ & 90 & 95 (69-99) & 82 & 94 (67-99) & 86 \\
\hline & Intermediate & $4(15)$ & 10 & 50 (5.8-84) & 67 & $50(5.8-84)$ & 72 \\
\hline
\end{tabular}


cohort to determine the classification and prognosis of patients with metastatic GCTs.

From the *Division of Medical Oncology, Queen Elizabeth II Health Sciences Centre, Halifax, NS, and the †Department of Medicine, Faculty of Medicine, Dalhousie University, NS

Acknowledgements: This project was funded by a Norah Stephen Oncology Scholars Summer Studentship Grant from Cancer Care Nova Scotia. Thank you to Sandra Bellefontaine for her administrative assistance.

This article has been peer reviewed.

Competing interests: None declared.

\section{References}

1. Oosterhof GON, Verlind J. Testicular tumours. BJU Int 2004;94:1196-201.

2. Canadian Cancer Society. Canadian Cancer Statistics 2008. Toronto: The Society; 2008. Available at: www.cancer.ca/Canada-wide/About\%20cancer/Cancer\%20statistics/ /media/CCS/Canada\%20wide/Files\%20list/English\%20files\%20heading/pdf\%20not \%20in\%20publications\%20section/Canadian\%20Cancer\%20Society\%20Statistics\%20PD F\%202008_614137951.ashx (accessed 2009 Feb 19).

3. Reuter VE. Origins and molecular biology of testicular germ cell tumors. Mod Pathol 2005; 18:\$51-60.

4. BosI GJ, Motzer RJ. Testicular germ-cell cancer. N Engl J Med 1997;337:242-53

5. Bosl GJ, Geller NL, Cirrincione C, et al. Multivariate analysis of prognostic variables in patients with metastatic testicular cancer. Cancer Res 1983;43:3403-7.

6. Birch R, Williams S, Cone A, et al. Prognostic factors for favorable outcome in disseminated germ cell tumors. J Clin Oncol 1986;4:400-7.
7. De Wit R, Stoter G, Sleiffer DT, et al. Four cycles of BEP versus an alternating regimen of PVB and BEP in patients with poor-prognosis metastatic testicular nonseminoma: a randomized study of the EORTC Genitourinary Tract Cancer Cooperative Group. Br J Cancer 1995;71:1311-4.

8. Bajorin D, Katz A, Chan E, et al. Comparison of criteria for assigning germ cell tumor patients to "good risk" and "poor risk" studies. J Clin Oncol 1988;6:786-92.

9. International Germ Cell Cancer Collaborative Group. International Germ Cell Consensus Classification: a prognostic factor-based staging system for metastatic germ cell cancers. J Clin Oncol 1997; 15:594-603.

10. Fever EJ, Frey CM, Brawley OW, et al. After a treatment breakthrough: a comparison of trial and population-based data for advanced testicular cancer. J Clin Oncol 1994; 12:368-77.

11. Harding MJ, Paul J, Gillis CR, et al. Management of malignant teratoma: Does referral to a specialist unit matter? Lancet 1993;341:999-1002.

12. Collette L, Sylvester RJ, Stenning SP, et al. Impact of the treating institution on survival of patients with "poor-prognosis" metastatic nonseminoma: European Organization for Research and Treatment of Cancer Genito-Urinary Tract Cancer Collaborative Group and the Medical Research Council Testicular Cancer Working Party. J Natt Cancer Inst 1999:91:839-46.

13. Aass N, Klepp 0, Cavallin-Stahl E, et al. Prognostic factors in unselected patients with nonseminomatous metastatic testicular cancer: a multicenter experience. J Clin Oncol 1991;9:818-26

14. Fever EJ, Sheinfeld J, Bos I GJ. Does size matter? Association between number of patients treated and patient outcome in metastatic testicular cancer. J Natl Cancer Inst 1999; 91:816-8.

Correspondence: Dr. Lori Wood, Division of Medical Oncology, Queen Elizabeth II Health Sciences Centre, Rm. 471, Bethune Building, 1278 Tower Rd., Halifax NS B3H 2Y9; fax 902 473-6186; lori.wood@cdha.nshealth.ca

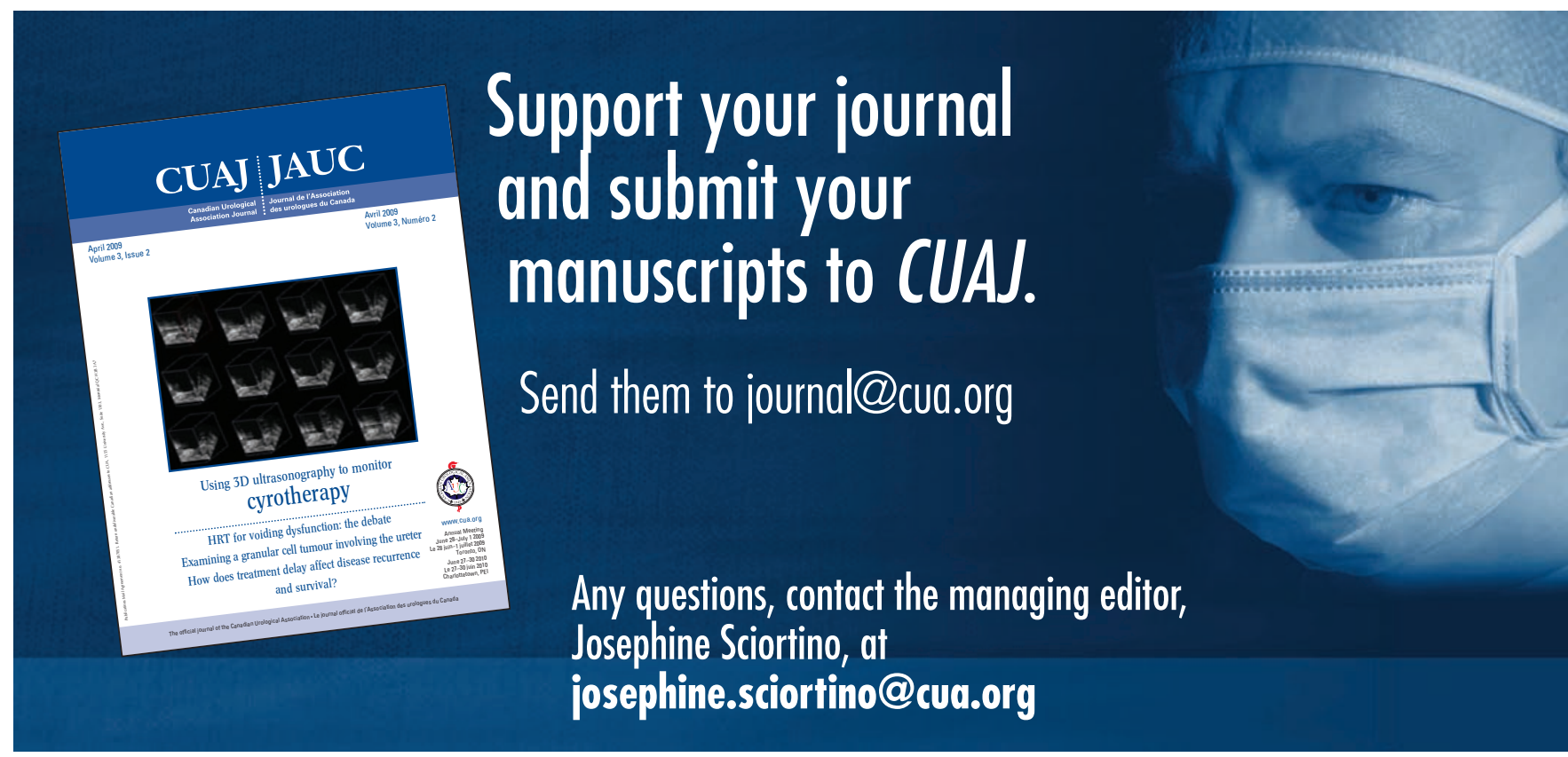

